\title{
AZ INNOVÁCIÓ FOGALMÁNAK ÉS FOLYAMATÁNAK TEORETIKUS MEGKÖZELÍTÉSE
}

\author{
SzlobodanVukoszavlyev
}

\begin{abstract}
Absztrakt: A világ fejlödése igencsak látványos folyamat, föképp, ha abból a szempontból nézzük, hogy hová jutott az emberiség az öskortól napjainkig. Ez a fejlödési folyamat, a folyamatos újítások, fejlesztések alapjaiban változtatták meg az emberiség életét. Ennek tükrében nemcsoda, hogy a közgazdaság-, gazđálkodás- és szervezéstudományok népszerü kutatási területei közé tartozik a fejlődésgazdaságtan ếs az innováció. A tanulmányban igyekszem átfogó képet adni az innováció fogalmi rendszerérỏl és megvilágítani az innováció, mint folyamat vagy társadalmi- gazdasági jelenség hátterében meghúzódó tényezöket. Bemutatom, hogy a XX. századtól kezdődően hogyan változott az innováció értelmezése, mi az, ami ma a gyakorlatban innovációnak tekinthető, miképp építhető be egy szervezet életébe az innováció és hogyan ágyazódik be az innováció megkerülhetetlenül az életünkbe.
\end{abstract}

\begin{abstract}
The development of the world is an attractive process, particularly when examining humanity from the prehistory up to the present days. This development process, the ongoing innovations and developments have changed the life of humanity fundamentally. Considering this process, development economics and innovation become popular research areas of economics, management and business. In this paper, innovation was defined comprehensively and elements underlying innovation as process or socio-economic phenomenon were highlighted. Changes of the definition were analysed from the 20th century and this paper also considers what innovation is in practice nowadays, how innovation can be introduced into an organisation or how innovation can be integrated into everybody's' life indispensable.
\end{abstract}

Kulcsszavak: innováció, innovációs modellek, innovációs folyamat

Keywords: innovation, innovation models, innovation process

\section{Bevezetés}

A világ fejlődése igencsak látványos folyamat, föképp, ha abból a szempontból nézzük, hogy hová jutott az emberiség az öskortól napjainkig. Ez a fejlődési folyamat, a folyamatos újítások, fejlesztések alapjaiban változtatták meg az emberiség életét. Ennek tükrében nemcsoda, hogy a közgazdaság-, gazdálkodás- és szervezéstudományok népszerü kutatási területei közé tartozik a fejlödésgazdaságtan és az innováció. A tanulmányban igyekszem átfogó képet adni az innováció fogalmi rendszeréről és megvilágítani az innováció, mint folyamat vagy társadalmigazdasági jelenség hátterében meghúzódó tényezőket. Bemutatom, hogy a XX. századtól kezdődően hogyan változott az innováció értelmezése, mi az, ami ma a gyakorlatban innovációnak tekinthető, miképp építhető be egy szervezet életébe az innováció és hogyan ágyazódik be az innováció megkerülhetetlenül az életünkbe.

\section{Az innováció fogalma}

Az innováció latin eredetủ szó, az innovare, innovatum igéből származik, mely két részből áll: az in- nyomatékosítást kifejező előtagból és a novus (új, újdonság) szóból, lefordítva megújítást jelent (Keresztes, 2013). Az innováció fogalmával és 
értelmezésével részletesebben a XX. századtól foglalkoztak. Az 1. táblázatban összegyüjtöttem a legfontosabb megközelítéseket nemzetközi, illetve hazai szinten.

Az innovációval elsőként alaposabban Schumpeter (1939) foglalkozott, munkássága alapjaiban meghatározta az innováció tudományos és üzleti megközelítését. Kiemelendő, hogy már Schumpeter sem kizárólag a radikális termékinnovációt értette a fogalom alatt, valamint megnevezte az innováció területeit is. Az innovációs gondolkodás fejlödésében lényeges pont Howard és Sheth (1969) munkája, a szerzőpáros határozta meg elsőként, hogy az innovációra relatív módon kell tekintenünk, azaz nemcsak az nevezhető innovációnak, ami az egész piac, gazdaság, társadalom számára új, hanem az is az innováció kategóriájába tartozik, ami a szervezet számára újdonságnak számít. Ezt a megközelítést mélyítette tovább Rogers és Shoemaker (1971), véleményük szerint minden újnak minösül, amit az egyén újnak észlel. A következő lényeges fejlödési pont Drucker 1985-ös munkája, ebben Drucker kiterjeszti az innováció fogalmát, megjelenik a társadalmi innováció fogalma és a szerző szerint nem lehet csupán a müszaki és gazdasági területre leszükíteni az innováció jelentőségét. Simmonds vezeti be a kreativitás szerepét az innovációs folyamatban 1986-ben. Értelmezése szerint a kreativitás abban segíti a szervezetet, hogy az a megszerzett ismereteket a korábban megszokotthoz képest eltérően, újfajta struktúrában képes implementálni.

$\mathrm{Az}$ innováció nemzeti és nemzetközi támogatási rendszere hívott életre egy nemzetközileg is elfogadható, közösen értelmezett definíciót. Elsőként az 1992-ben megjelent Oslo kézikönyv próbált megoldást kínálni erre a problémára, melyet az OECD jelentetett meg. Ez a definíció azonban a termék- és eljárás innovációra helyezte a hangsúlyt, valamint külön definiálta az egyes kategóriákat (radikális termékinnováció, módosító termékinnováció, eljárás innováció). További bonyodalmakra adhat okot az OECD által 2002-ben megjelentetett Frascatti kézikönyv, ami a tudományos kutatás és fejlesztéssel foglalkozik, ezeket pedig egyértelmủen az innováció körébe sorolja, ezzel ellentétben jelenleg a hazai gyakorlat a Nemzeti Kutatási és Fejlesztési Innovációs Hivatal (röviden: NKFI) szétválasztja a kutatást és fejlesztést az innovációtól. Talán a mai gyakorlatban leginkább elterjedt meghatározása az innovációnak az Oslo kézikönyv harmadik kiadásában jelent meg 2006-ban. A kézikönyv e kiadása részletesen és egyértelmüen meghatározza az innováció fogalmát és az innováció eseteit is magyarázza. Problémás helyzetet szül, hogy a hazai gyakorlatban az innováció definíciójának harmonizációja csak részben valósult meg. A jogalkotó a tudományos kutatásról, fejlesztésről és innovációról szóló 2014. évi LXXVI. törvényben meghatározza a fogalmat, tehát jogilag Magyarországon ez az alkalmazandó definíció, ezzel ellentétben az NKFI eltér ettöl. Véleményem szerint lényegi különbség a két fogalom között nincs, ugyanakkor államigazgatási szinten elvárható lehet, a fogalom harmonizációja, ha erre a jogalkotó törvényben kitér. Érdekesség, hogy a hazai tudományos megközelítésben Chikán Attila a Magyar Tudományos Akadémia tagja a népszerü Vállalatgazdaságtan címü könyvében egy új megközelítést alkalmaz, melyben talán a vevőorientáció szerepe jelenik meg kardinálisan véleményem szerint. 


\begin{tabular}{|c|c|}
\hline Szerzö & Meghatározás \\
\hline Schumpeter (1939) & $\begin{array}{l}\text { Egy új vagy módosított termék piaci bevezetése: } \\
\text { - ưj termék bevezetése az iparágban } \\
\text { - új termelési eljárás/módszer bevezetése } \\
\text { - új piac felfedezése } \\
\text { - új forrás felfedezése az inputok piacán } \\
\text { - új szervezet létrehozása }\end{array}$ \\
\hline Drucker (1954) & A szervezet két alapfunkciójának egyike. \\
\hline $\begin{array}{l}\text { Howard-Sheth } \\
(1969)\end{array}$ & Bármi új elem értékesítése függetlenül attól, hogy új vagy sem a szervezet számára. \\
\hline $\begin{array}{l}\text { Rogers-Shoemaker } \\
\text { (1971) }\end{array}$ & Új ötlet, amit az egyên újnak észlel. \\
\hline Downs-Mohr (1976) & $\begin{array}{l}\text { Bármely olyan eszköz, rendszer, folyamat, probléma, termék vagy szolgáltatás adaptációja, } \\
\text { ami a szervezet számára új. }\end{array}$ \\
\hline Drucker (1985) & $\begin{array}{l}\text { Az innovációra az élet minden területén szükség van, az ínnováció nem kizárólag mũszaki } \\
\text { vagy gazdasági jelenség. }\end{array}$ \\
\hline Simmonds (1986) & $\begin{array}{l}\text { (1) Ưj ötlet, aminek a tartalma lehet: új termék és szolgáltatás, egy létezỏ termék új } \\
\text { felhasználási lehetősége, új piac egy létezõ termék számára, új marketing módszer. } \\
\text { (2) Alapvetơen egy kreatív folyamat. }\end{array}$ \\
\hline Oslo Manual (1992) & $\begin{array}{l}\text { Megkülönböztet termék- és eljárás innovációt, a termékinnováción belül különbséget tesz } \\
\text { a radikális és a módosító termékinnováció közt. Radikális termékinnováció: olyan új } \\
\text { termék, amelynek felhasználása, teljesítmény jellemzöi, tulajononságai, } \\
\text { tervezésisajátosságai, anyagfelhasználása vagy alkatrészei jelentösen eltérnek a korábbi } \\
\text { konstrukciótól. Módosító termékinnováció: egy meglévö termék teljesítményének jelentős } \\
\text { javítása, nagyobb teljesítményũ alkatrészek vagy jobb minőségũ anyagok felhasználásával. } \\
\text { Eljárás-innováció: új, vagy jelentősen javított gyártási módszerek alkalmazása. }\end{array}$ \\
\hline Davenport (1993) & Egy feladat végrehajtása radikálisan új módon. \\
\hline $\begin{array}{l}\text { Henderson-Lentz } \\
\text { (1996) }\end{array}$ & Innovatív ötletek implementácioja. \\
\hline $\begin{array}{l}\text { Dougherty-Hardy } \\
(1996)\end{array}$ & $\begin{array}{l}\text { Ủj termék vagy szolgáltatás megalkotása, fejlesztése, gyártmányfejlesztése, gyártása, } \\
\text { piacra vitele és folyamatos menedzselése. }\end{array}$ \\
\hline Bocr-During (2001) & A termék-piac-technológia-szervezet új kombinációja. \\
\hline $\begin{array}{l}\text { OECD: Frascatti } \\
\text { kézikönyv (2002), } \\
\text { magyar fordításban } \\
\text { 2004-ben }\end{array}$ & $\begin{array}{l}\text { Az innovációs folyamat részének tekinti a } \mathrm{K}+\mathrm{F} \text { folyamatokat } \mathrm{s} \text { ezen belül három típust } \\
\text { különböztet meg: alapkutatás, alkalmazott kutatás, kísérleti fejlesztés. }\end{array}$ \\
\hline Oslo Manual (2006) & $\begin{array}{l}\text { „Az innováció } \\
\text { - új. vagy jelentősen javított termék (áru vagy szolgáltatás) vagy eljárás, } \\
\text { - új marketing-módszer, vagy } \\
\text { - új szervezési-szervezeti módszer bevezetése } \\
\text { - az üzleti gyakorlatban, munkahelyi szervezetben, vagy a külsó kapcsolatokban.” Az } \\
\text { innováció területeit egyenként definiálja. }\end{array}$ \\
\hline Chikán (2008:31) & „.... a fogyasztói igények új, magasabb minöségi szinten való kielégítése..." \\
\hline $\begin{array}{lr}2014 . \text { évi } & \text { LXXVI. } \\
\text { törvény } & \text { a } \\
\text { tudornányos } & \\
\text { kutatásról. } & \\
\text { fejlesztésröl } & \text { és } \\
\text { innovációról }\end{array}$ & $\begin{array}{l}\text { „a gazdasági tevékenység hatékonyságának, jövedelmezóségének javítása, a kedvezõ } \\
\text { társadalmi és kömyezeti hatások elérése érdekében végzett tudományos, müszaki, } \\
\text { szervezési, gazdálkodási, kereskedelmi müveletek összessége, amelyek eredményeként új } \\
\text { vagy lényegesen módosított termék, eljárás, szolgáltatás jön létre, új vagy lényegesen } \\
\text { módosított eljárás, technológia alkalmazására, piaci bevezetésére kerül sor, ideértve azokat } \\
\text { a változásokat, amelyek csak adott ágazatban vagy adott szervezetnél minōsülnek } \\
\text { újdonságnak" }\end{array}$ \\
\hline $\begin{array}{lr}\text { Nemzeti } & \text { Kutatási, } \\
\text { Fejlesztési } & \text { és } \\
\text { Innovációs } & \text { Hivatal }\end{array}$ & $\begin{array}{l}\text { „Az innováció lehet egy új termék (új fogyasztói javak elöállítása), új termelési eljárás } \\
\text { (megújított termelés, vagy szállítási módszer), új piac (új piacok, új elhelyezési lehetőség } \\
\text { megnyitása), új nyersanyag (újfajta nyersanyagok és félkész ánuk használata, beszerzési } \\
\text { forrásainak megnyitása), vagy egy új szervezet, újfajta vállalati, vagy iparági szervezés } \\
\text { létrehozása vagy megszüntetése. Ismert a termékinnováció, eljárás innováció, marketing } \\
\text { innováció, szervezeti innováció megkülönböztetés, továbbá az innovatív üzleti modell is." }\end{array}$ \\
\hline
\end{tabular}

Forrás: saját szerkesztés saját gyüjtés alapján. 


\section{Az innováció mögötti fogalmi rendszer}

Szorosan kapcsolódó és a gyakorlatban gyakran összemosódó fogalom a $\mathrm{K}+\mathrm{F}+\mathrm{I}$ (kutatás, fejlesztés és innováció) hármasa. Ahhoz, hogy pontosan el tudjuk határolni egymástól ezeket (ha ez cél és egyáltalán lehetséges) meg kell vizsgálnunk az innováció életciklusát és be kell vezetnünk a pontosabb lehatárolás érdekében három újabb kategóriát: invenció; innováció és diffúzió (Schumpeter, 1939; Śledzik, 2013). Tévedés forrása lehet, ha egy-egy ötlet megszületését, legyen az akár egy új vagy jelentősen megújított termék, szolgáltatás, technológia, szervezeti-szervezési eljárás, marketing módszer felfedezését vagy megalkotását az innováció kategóriájába soroljuk. Mindaddig amíg ezek az ötlet szintjén léteznek és bevezetésük vagy alkalmazásuk még nem történt meg a gyakorlatban (sem az üzleti gyakorlatban, sem a vállalati szervezetben) addig csupán invencióról van szó. Crawford (1987) úgy definiálja az invenciót, hogy az nem más, mint valaminek (tudásnak vagy tárgynak) a létrehozása, ami korábban nem létezett, szerinte az invenció egy kreatív, felfedezö folyamat. Jóllehet az invenció léte nélkülözhetetlen az innovációhoz, azonban észre kell vennünk, hogy az invenció részét képezik a gyakorlatban megvalósíthatatlan vagy bármilyen egyéb ok miatt megvalósításra nem kerülö fejlesztések, ötletek is. Schumpeter (1939) az invenció gyakorlati megvalósításától, kifejlesztésétől kezdődően határozza meg az innováció kezdetét. Szemléltető példa Schumpeter magyarázata: az inventor az invenció megalkotója, egy feltaláló, az invenciót felhasználó pedig egy innovátor, akit az üzleti haszon elérése motivál. Schumpeter (1939) innovációs életciklusának harmadik pontja a diffúzió, ami az innováció széleskörü elterjedését és az innováció hatásának kibontakozását takarja. A következő ábra szemlélteti Schumpeter invenció-innováció-diffúzió hármas modelljének összefüggését (1. ábra).

\section{1. ábra: Az invenció-innováció-diffúzió kapcsolódási pontjai}
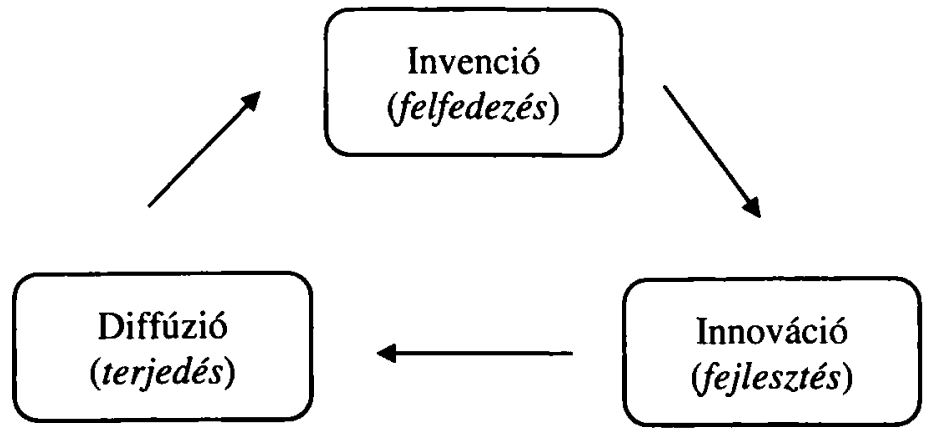

Forrás: Saját szerkesztés Schumpeter (1939) alapján.

Leegyszerüsítve az eddig leírtakat azt mondható, hogy Schumpeter (1939) alapján az invenció egy új ötlet megszületése, az innováció az invenció piacon első ízben és üzleti céllal megvalósított formája a diffúzió pedig az innováció elterjedése. Megfigyelhető, hogy az ábrán irányul egy nyíl a diffúzióról az invenció irányába, ez a nyíl a folyamatos fejlesztésekre és az újabb invenció megszületésére utal. 
Az invenció és innováció fogalma Hisrich és Peters (1992) munkásságában is megjelenik, azonban a szerzőpáros nem követi Schumpeter (1939) terminológiáját. Véleményük szerint az innovációnak négy típusa van az eredetiség szempontjából: invenció; továbbfejlesztés; utánzás és szintézis. Az invenció egy új és eredeti ötlet ugyanakkor még nem innováció, csak akkor válik azzá, ha piacképes termékké válik. Ez esetben terminológiai ellentmondást fedezhetünk fel, mivel az invenciót az innováció egyik típusának nevezik ugyanakkor egyértelmüen szét is választják a két fogalmat. Véleményem szerint ez esetben a szerzőpáros itt az invención alapuló innovációra gondolt, bár az elnevezése semmiképp nem tekinthető szerencsésnek. Hasonló terminológiai ellentmondással a továbbiakban nem találkozhatunk a munkájukban. A továbbfejlesztés eseténél egyértelmüen definiálják, hogy az innováció azon esetéről van szó, amikor egy meglévő terméket vagy szolgáltatást más területen vagy új formában alkalmaznak. Az utánzás esete az eredeti termék vagy szolgáltatás klónozása, míg a szintézis több már létező termék vagy szolgáltatás új módon történő kombinálása vagy új típusú felhasználása (Hisrich-Peters, 1992).

A gyakorlatban szintén problémás lehet a kutatás, fejlesztés és innováció értelmezése, holott egyértelmúen különbözö folyamatokról van szó, mégis elöfordul, hogy az innováció tartalmi elemei közé keveredik a kutatás és a fejlesztés. Logikailag könnyen belátható, hogy ez téves elgondolás, ha bevezetjük a kutatás és a fejlesztés általánosan elfogadott meghatározását. A Nemzeti Kutatási, Fejlesztési és Innováció Hivatal meghatározása szerint: „a $\mathrm{K}+\mathrm{F}$ alapvetően a rendszeresen végzett alkotó munka, amelynek célja az ismeretanyag, a tudásbázis bővítése”. A $\mathrm{K}+\mathrm{F}$ alatt általában három egymástól jól eltérő, jól definiált folyamatot különböztetünk meg. A tudományos kutatásról, fejlesztésről és innovációról szóló 2014. évi LXXVI. törvény ezeket definiálja:

„alapkutatás: olyan felfedező jellegü kísérleti vagy elméleti munka, amelyet elsösorban jelenségek, tapasztalatok és megfigyelések megértéséhez szükséges új ismeretek megszerzésének érdekében folytatnak anélkül, hogy kilátásba helyeznék azok gyakorlati alkalmazását vagy felhasználását,

alkalmazott kutatás: tervezett kutatás vagy célzott vizsgálat, amelynek célja új ismeretek, tudás és szakértelem megszerzése új termékek, eljárások, technológiák vagy szolgáltatások kifejlesztéséhez, vagy a létezö termékek, eljárások vagy szolgáltatások jelentős mértékủ továbbfejlesztésének elösegítéséhez".

Az alapkutatás és az alkalmazott kutatás esetén egyértelmü, hogy ezek közvetve vagy közvetlenül szolgálhatják az innovációt, de az innovációs folyamatba nem tartoznak, a 2014. évi LXXVI. törvény által definiált innováció részét nem képezik. Egy árnyalattal nehezebb a különbségtétel azonban az innováció és a kísérleti fejlesztés között. A jogalkotó úgy fogalmaz, hogy a „kísérleti fejlesztés: a meglévő tudományos, technológiai, üzleti és egyéb vonatkozó ismeretek és szakértelem megszerzése, összesítése, megosztása, alkalmazása és felhasználása új, módosított vagy javított termék, eljárás vagy szolgáltatás terveinek létrehozása vagy megtervezése céljából..." (2014. évi LXXVI. törvény), továbbá a pontosítás érdekében a jogalkotó meghatározza azokat az eseteket is, amik kísérleti fejlesztésnek minősülhetnek. Összefoglalva és leegyszerüsítve a törvényi 
meghatározást úgy fogalmazhatunk, hogy az alapkutatás során a folyamat célja új ismeretek megszerzése, a tudásállomány bővítése üzleti haszonszerzés nélkül, az alkalmazott kutatás esetében már a fỏ motívum az elérendő haszon, a folyamat e célnak van alárendelve. A kísérleti fejlesztés esetén véleményem szerint a folyamat célja az innováció támogatása, a kulcsmotívum jelen esetben is az üzleti haszon elérése lehet.

\section{Innovációs modellek}

Az innovációs folyamat gyakorlati megvalósításának pontos megértéséhez és az innovációs gondolkodás fejlődésének bemutatásához segítséget nyújthatnak az innovációs modellek. Ezek az innovációs modellek az innovációt folyamatában mutatják, megjelenítve, hogy milyen szakaszok azonosíthatók és azok közt milyen kapcsolódás található. Ezeket a modelleket generációknak tekintjük, ez alapján feltételezett az innováció innovációja vagy az innováció magasabb szintủ megértése, esetleg az innováció minél eredményesebb igazítása a változó piaci környezethez. A 2. táblázatban az innovációs modellek összehasonlítása látható a különböző szerzők megközelítése alapján.

2. táblázat: Az innovációs modellek összehasonlítása

\begin{tabular}{|c|c|c|c|c|}
\hline Generáció & $\begin{array}{c}\text { Rothwell } \\
\text { (1994) }\end{array}$ & $\begin{array}{c}\text { Marinova és Phillmore } \\
(\mathbf{2 0 0 3 )}\end{array}$ & $\begin{array}{c}\text { Berkhout et al. } \\
(2006)\end{array}$ & $\begin{array}{c}\text { Bochm; Frederick } \\
\text { (2010) } \\
\end{array}$ \\
\hline Elsö & $\begin{array}{l}\text { Technoló } \\
\text { giai tolás }\end{array}$ & Fekete doboz modell & $\begin{array}{c}\text { Technológiai } \\
\text { tolás }\end{array}$ & Technológiai tolás \\
\hline Második & $\begin{array}{l}\text { Piaci } \\
\text { húzás }\end{array}$ & Lineáris modellek & Piaci húzás & A kereslet húzása \\
\hline Harmadik & $\begin{array}{c}\text { Kapcsolt } \\
\text { modell }\end{array}$ & Visszacsatolásos modell & $\begin{array}{l}\text { Az első és } \\
\text { második } \\
\text { generációs } \\
\text { modell } \\
\text { kombinációja } \\
\end{array}$ & Portfólió menedzsment \\
\hline Negyedik & $\begin{array}{l}\text { Integrált } \\
\text { modell }\end{array}$ & Rendszer modell & $\begin{array}{c}\text { Ciklikus } \\
\text { innováció } \\
\text { modellje }\end{array}$ & Integrált menedzsment \\
\hline Ötödik & $\begin{array}{l}\text { Párhuzam } \\
\text { os és } \\
\text { integrált } \\
\text { modell }\end{array}$ & Evolúciós modell & - & Rendszer integráció \\
\hline Hatodik & - & Innovációs környezet & - & Hálózati integráció \\
\hline
\end{tabular}

Forrás: Saját szerkesztés Taferner, 2017 alapján.

Az első és a második generációs modelleket lineáris modelleknek tekintjük, mert az innovációt egy véges, meghatározott szakaszokból álló folyamatként értelmezik, ahol a szakaszok egymásra épülnek és az egyik szakasz lezárását követően kezdődik a következő szakasz. A terület meghatározó szerzöi túlnyomórészt egyet értenek abban, hogy a lineáris toló és húzó innovációs modell tekinthető ez első- és másodikgenerációnak. 
Az elsőgenerációs modellt logikai felépítése alapján nevezhetjük szükségletteremtő vagy technológiavezérlt innovációs modellnek is (2. ábra). Az elsőgenerációs technológiai tolásra épülő innováció alapgondolata, hogy az innovációs folyamat valamilyen új kutatási eredményből származik, ezek a kutatási eredmények részben a technológiai fejlödés ösztönző hatásának köszönhetők, ugyanakkor a fejlesztés és az innováció elébe meg a fogyasztói igényeknek, kvázi teljesen kizárja a folyamatból a piaci keresletet. A modell az állami vagy magán $\mathrm{K}+\mathrm{F}$ központokban létrejött tudományos ismeretekre épül, melyek implementálása az innováció feladata (Barbieri et al., 2016; Rothwell, 1994).

\section{2. ábra: Technológiai tolás}

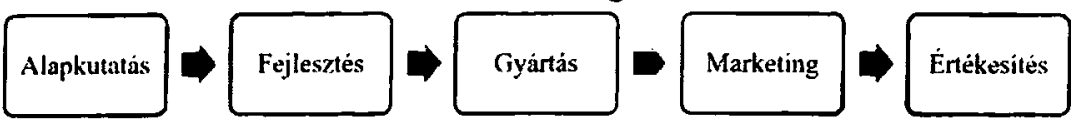

Forrás: Saját szerkesztés Rothwell, 1994 alapján.

A folyamatban elsősorban a termelés és termékkoncepció jellemzői, valamint a folyamat elörehaladását követően az értékesítési koncepció motívumai fedezhetők fel a marketingszemlélet teljes hiánya mellett.

másodikgenerációs modell a piaci vagy keresleten alapuló húzásra épít (3.ábra). Leegyszerüsítve úgy is nevezhetjük, hogy ez egy szükségletkövető vagy piacvezérelt innováció. Ezt az újfajta megközelítést a piaci verseny kiéleződése hívta életre. A piacon lassan kialakuló túlkínálat oda vezetett, hogy a vállalatoknak olyan értéket kellett felkínálniuk a piacon, melyre valós igény jelentkezik. Leegyszerüsítve nem azt kell gyártani, amit létre tudunk hozni, hanem azt kell létrehozni és legyártani, amire a piacon igény van. Ennek a felfogásnak a megjelenése az Egyesült Államokban nagyjából az 1960-as, 1970-es évekre tehető, a folyamatban pedig egyértelmüen fellelhetők a marketingkoncepció ismertetö jegyei, elsősorban a vállalat által megvalósított vevőorientáció (Rothwell, 1994; Kotler-Keller, 2012).

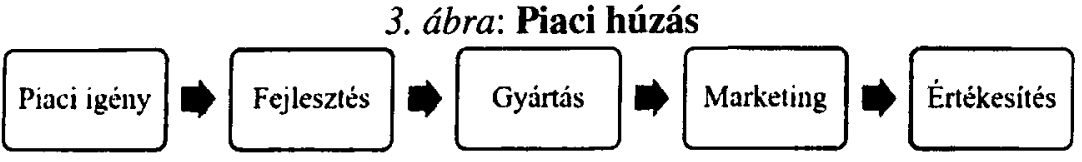

Forrás: Saját szerkesztés Rothwell, 1994 alapján.

A Bár a másodikgenerációs lineáris modell sok tekintetben elörébb mutató, mégis a lineáris modellek közös problémája a szükségletkövető modellt is terheli, azaz mindkét modell egy belátható, egyirányú, véges, a részek egymásra épülését feltételező metodikát követ.

A lineáris modellek közös hibájának a kiküszöbölésére Rothwell (1994) alapján a visszacsatolásos modell képes megoldást adni (4. ábra). Ez a modell összekapcsolja a lineáris modelleket és kiemeli, hogy a piaci igényeknek nemcsupán a folyamat elején van szerepe, hanem a folyamat valamennyi lépésében, továbbá kiemeli, hogy az innováció végeredményét nem lehet a kezdetekben pontosan meghatározni. 
4. ábra: A visszacsatolásos modell

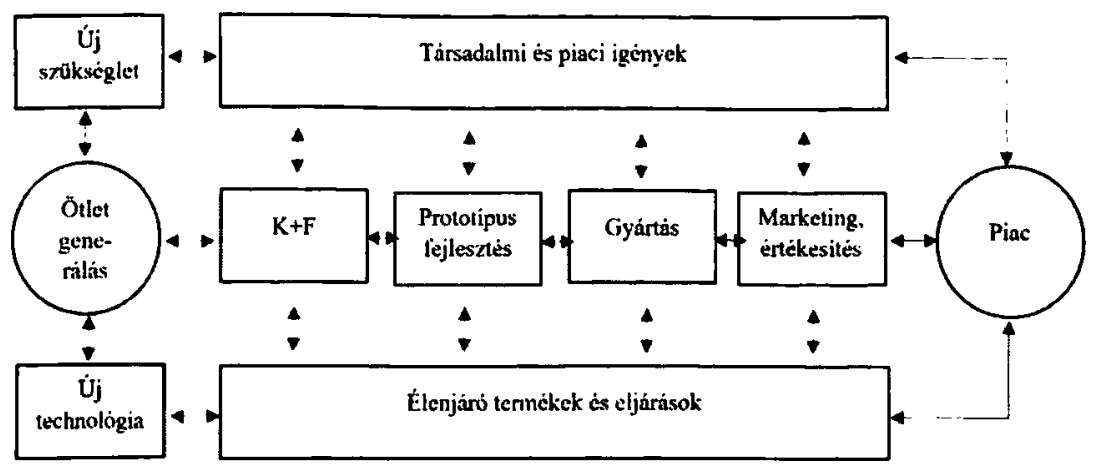

Forrás: Saját szerkesztés Galankis, 2006 alapján.

Véleményem szerint a visszacsatolásos modell elsősorban abban mutat jelentős különbséget a szükségletkövető modellhez képest, hogy jóval nagyobb rugalmasságot biztosít a folyamatban, azonban ez a rugalmasság vegyük észre csak akkor számít, ha a projektmenedzser vagy az innovációs folyamat koordinátora rendelkezik azokkal az attitüdökkel és szemlélettel, hogy az innovációba „beengedjen” egy folyamatos iterációt és vállalja, hogy ezáltal a folyamat komplexitása fokozódik.

Az innováció eredményeinek (termékek, technológiák, eljárások, módszerek) az életciklusának a rövidülése, valamint a tovább erősödő verseny vezetett oda, hogy a visszacsatolásos innováció újra gondolása vált szükségessé. $\mathrm{Az}$ innovatív tevékenységek párhuzamos voltának felismerése magával hozta, hogy (1) a vállalaton belüli innovációs folyamatok integrációja szükséges, (2) az innovációs folyamat átlépi a szervezet határát és sokszereplős együttműködések elött nyílik meg a kapu akár a szállítók, felhasználók és versenytársak bevonásával. Az 5. ábrán látható a negyedikgenerációs innovációs modell: az integrált modell (BochmFrederick, 2010). Véleményem szerint a modell logikájának ábrázolása Rothwell (1994) grafikus szemléltetésén nem adja át azt, hogy az innovációs folyamat elött megnyílnak a szervezet határai, csupán azt hangsúlyozza az ábra, hogy a szervezeten belül integráció valósul meg. Ennek ellenére vegyük észre, hogy az integrált modell már igazi áttörést jelentett az innovációs gondolkodás fejlödésében, mert felismerte annak többszereplös (esetleg hálózatos) mivoltát. 


\section{5. ábra: Az integrált modell}

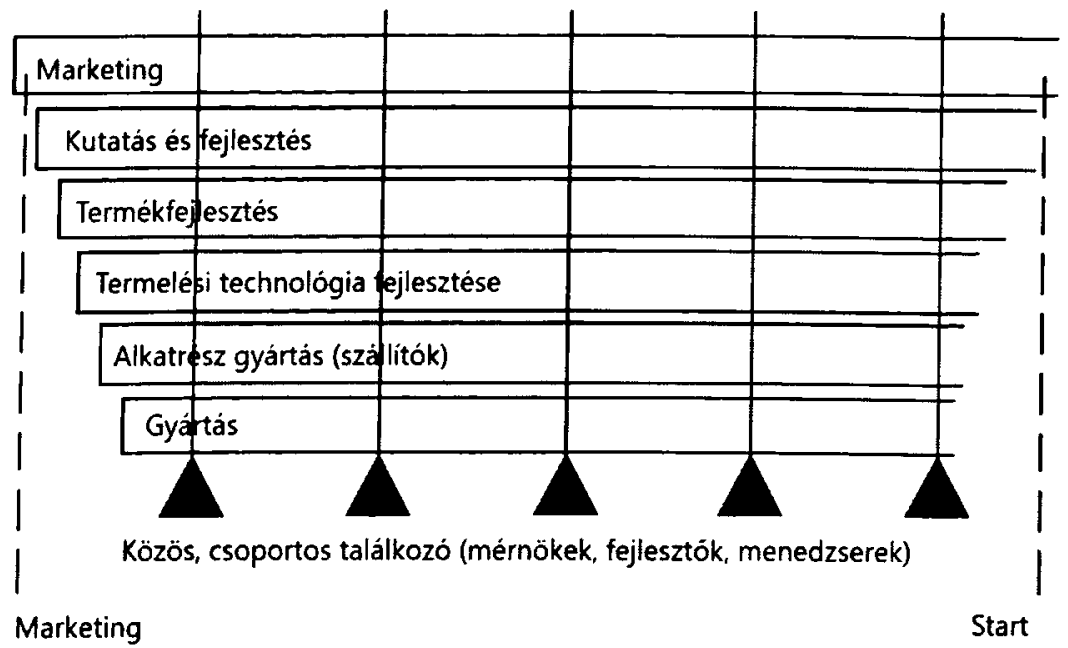

Forrás: Saját szerkesztés Rothwell, 1994 alapján.

$\mathrm{Az}$ integrált modell kibövítésének tekinthető az ötödikgenerációs innovációs modell, ami a tudás által vezérelt gazdaságban integrált módon közelíti meg az innovációt, miközben tartalmazza a korábbi modellek lényeges paramétereit ( 6 . $a ́ b r a)$. A folyamat komplexitását jól jelzi, hogy kibövíti az informatikai eszközök és irányítási rendszerek kiemelt szerepével, valamint, hogy a gyártás szempontjainak érvényesülniük kell már az elözetes tervezések során is. Összefoglalva a modellben innováció gyors és folyamatos implementálásának az alapja az integrált hálózatok és rendszerek intenzív és rugalmas használata (Rothwell, 1994; Galankis, 2006). A gyakorlatban a Triple és Quadruple Helix modellek megvalósítása már igen közel állónak tekinthető az ötödikgenerációs modellhez.

Marinova és Phillmore (2003) ötödikgenerációs innovációs modelljét a darwini evolúció ihlette. Véleményük szerint az innováció az evolúció egyik fajtája a modern társadalomban, ahol a fajták létrejötte az innovációs folyamatok produktuma, ezek természetes szelekcióját (hosszútávon pedig azt, hogy melyik vállalatok maradnak a piacon) a piacgazdaságban folyó verseny szavatolja.

Ma már találkozhatunk az innováció hatodikgenerációs modelljeivel is, elsösorban angol nyelvü folyơiratok közleményeiben. Marinova és Phillmore (2003) munkássága alapján ezt az új generációt a teljesmértékủ hálózatos integritás jellemzi, a modell központi eleme az innovációs környezet, amit a tudásállomány és az egyéni kompetenciák kreatív kombinációjaként értelmeznek. További kulcselemként jelenik meg a szerzőpáros munkásságában, hogy az innovációs környezet szerves elemének tekinti mindezek mellett a helyi szervezeteket, a technológiai, valamint a gazdasági folyamatokat. Továbbá véleményük szerint az innovációs hálózatokban nem szükségszerü a formalizált együttmüködés (pl. stratégiai szövetségek által deklarált), mert az innovációs környezet, mint hatodikgenerációs modell, nem a vállalat által irányított, tervezett, szervezett innovációs folyamat, hanem egy külső 
adottság, amit a környezet generál a felhasználók, fogyasztók, versenytársak, társadalmi, kulturális, gazdasági feltételek és tényezők (Marinova-Phillmore, 2003).

\section{6. ábra: Az ötödikgenerációs innovációs modell}

A vállalat belsõ adottságai

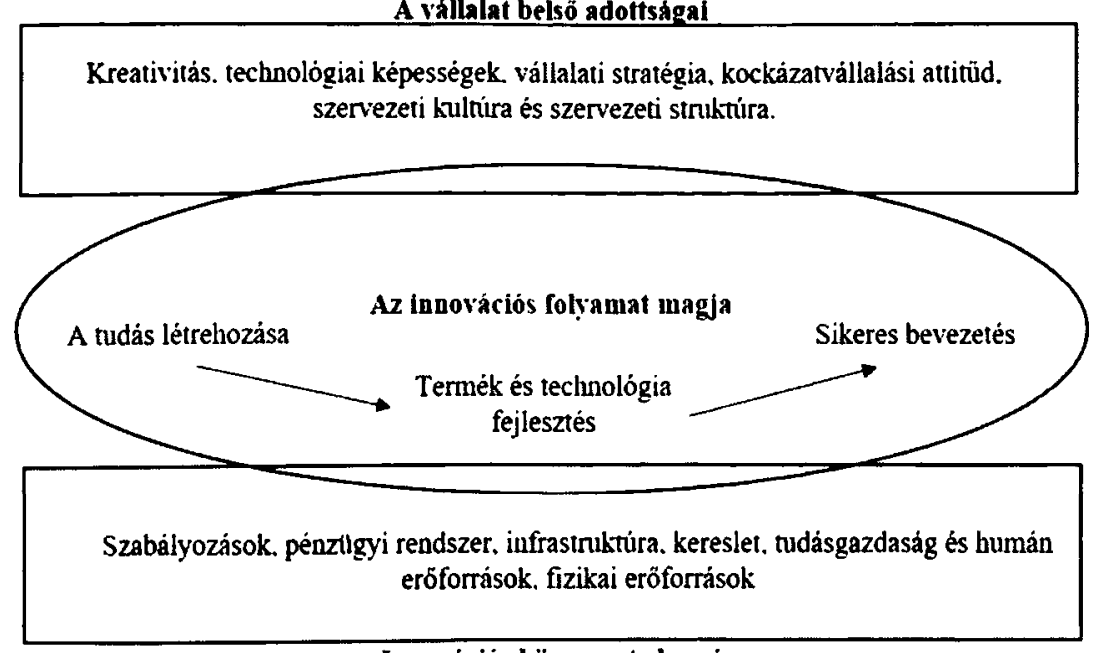

Innovációs köruyezet elemeí

Forrás: Saját szerkesztés Galankis, 2006 alapján.

Véleményem szerint a hatodikgenerációs innovációs modellnek már az értelmezése is nehézkesebb az elözőkénél, a gyakorlati implementálása pedig már a leírásából adódóan is jelentös korlátokban ütközik, már azért is, mert megvalósítása nem csupán vállalati feladat. Azonban úgy gondolom, hogy ha adott az innovációs környezet a vállalat számára - vagy legalábbis valamilyen mértékben jelen van - egy alternatív megoldás lehet az innovációmenedzsment számára a nyitott innováció ( 7 . ábra).

A nyitott innováció folyamata során tudatosan gyüjtjük be és dolgozzuk fel a vállalaton kívülröl érkező gondolatokat, tapasztalatokat, ismereteket és aknázzuk ki a környezetünkben lévők eszközeit, képességeit, kompetenciáit annak érdekében, hogy egy versenyképesebb terméket, szolgáltatást, eljárást, üzleti modellt tudjuk alkotni (Szakály, 2008). Alapelve, hogy nem áll rendelkezésre a vállalat számára minden erőforrás vagy, hogy nem a vállalatnál vannak a legversenyképesebb eröforrások, ugyanakkor ez nem zárja ki a lehetőségét mások erőforrásának a hasznosítására. 


\section{7. ábra: A nyitott innováció gondolata}

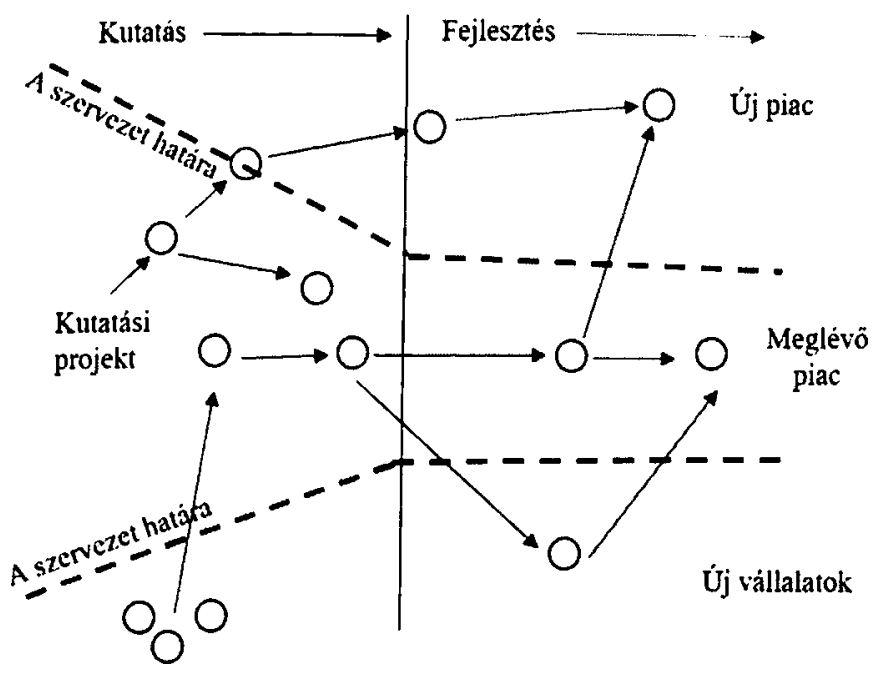

Forrás: Saját szerkesztés Binci-Cerruti, 2014 alapján.

\section{5. Összefoglalás}

Véleményem szerint az innováció mindig is a társadalmi és gazdasági fejlődés alapja volt, az emberiség hajnalától kezdve átszötte életünket. Az, hogy a gazdaság müködéséről létrejött tudásállományunk egyre szofisztikáltabban közelíti meg az innováció és az innovációmenedzsment kérdéskörét, nem jelenti azt, hogy egy teljesen újkeletü jelenségröl lenne szó. Sokkal inkább arra helyeződik a hangsúly, hogy minél jobban feltárjuk a müködését annak érdekében, hogy a változó környezeti feltételekhez a legeredményesebben tudjuk illeszteni az eseti, gyakorlati problémák megoldását.

A tanulmány első felében feltártam az innováció fogalmi fejlödésének legfontosabb állomásait a fogalom megjelenésétől a mai üzleti gyakorlatban bevett meghatározásig. A második részben pedig bemutattam az innovációs folyamat, $\mathrm{s}$ ezzel részint az innovációmenedzsment bizonyos területének az átalakulását, mely fejlödésnek az oka részben a gazdaság és a piac müködésének minél magasabb szintü megismerése, részben a változó piaci és környezeti adottságok.

\section{Irodalomjegyzék}

2014. évi LXXVI. törvény: tudományos kutatásról, fejlesztésröl és innovációról.

Barbieri, J. C., Álvares, A. C. T. (2016): Sixth generation innovation model: description of a success modell. RAI Revista de Administracao e Inovacao, 13 (2): 116-127.

Binci, D., Cerruti, C. (2014): Open innovation!. Management Innovation Newletter, No. 2. In: Taferner, B. (2017): A next generation of innovation models? An integration of the innovation process model big picture towards the different generations models. Review of Innovation and Competitiveness, 3 (3): 47-60.

Berkhout, A. J., Hartmann, D., Duin, P., Ortt, R. (2006): Innovating the innovation process. International Journal of Technology Management, 34 (3-4): 390-404. 


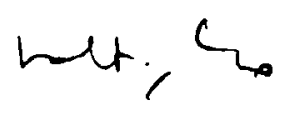

$220 \bullet$ Vukoszavlyev $S z$.

Bochm, G., Frederick L. J. (2010): Strategic innovation management in global industry networks. Asian Journal of Business Management, 2 (4): 110-120.

Boer, H., During, W. E. (2001): Innovation, What Innovation? A Comparison between Product, Process and Organizational Innovation. International Journal of Technology Management, 22 (1/2/3): 83-107.

Chikán A. (2008): Vállalatgazdaságtan. AULA Kiadó, Budapest.

Crawford, C. M. (1987): New products management (2nd ed.). Homewood, IL: Irwin.

Davenport, T. H. (1993). Process innovation: Reengineering work through information technology. Harvard Business School Press, Boston, Mass.

Dougherty, D., Hardy, C. (1996): Sustained Product Innovation Mature Organizations: Overcoming Innovation-to-Organization Problems. The Academy of Management Journal, 35 (5): 1120 1153.

Downs, G. W., Mohr., L. B. (1976): Conceptual issues in the study of innovation. Administrative Science Quarterly, 21 (4): 700-714.

Drucker, P. F. (1954): The practice of management (1st ed.). Harper \& Row, New York,

Drucker, P. F. (1985): Innovation and Entrepreneurship. Harper Collins Publishers.

Galanakis, K. (2006): Innovation process: Make sense using systems thinking. Technovation, 26 (11): 1222-1232.

Henderson, J. C., Lentz, C. M. C. (1996): Learning, Working, and innovation: A Case Study in the Insurance Industry. Journal of Management Information Systems, 12 (3): 43-64.

Hisrich, R., Peters, M. (1991): Vállalkozás. Akadémiai Könyvkiadó, Budapest.

Howard, J. A., Sheth, J. N. (1969): The theory of buyer behaviour. Wiley, New York.

Keresztes G. (2013): Az innováció fogalmának történeti áttekintése. Gazdaság \& Társadalom, 5 (4): 81-95.

Kotler P., Keller, K. L. (2012): Marketingmenedzsment. Akadémiai Kiadó, Budapest.

Marinova, R., Phillimore, J. (2003): Models of innovation. In: Shavinina, V. (szerk.): Intermational handbook on innovation, Elserver, Amsterdam, 44-53.

Nemzeti Kutatási, Fejlesztési és Innovációs Hivatal honlapja: Fogalomtár. <http://nkfih.gov.hu/szakpolitika-strategia/fogalomtar/fogalomtar> (2018.03.02.)

OECD (1992): Oslo Manual (1st ed.). <https://www.oecd.org/sti/inno/ 2367580.pdf> (2018.03.20.)

OECD (2002): Frascatti kézikönyv. 〈http://nkfih.gov.hu/hivatal/kiadvanyok-kfi/frascati-kezikonyv〉 (2018.03.25.)

OECD (2006): Oslo Manual (3rd ed.). <http://www.oecd.org/sti/inno/oslo manualguidelinesforcollectingandinterpretinginnovationdata3rdedition.htm> (2018.03.20.)

Rogers, E. M., Shoemaker, F. F. (1971): Communication of innovations: a cross-cultural approach. Free Press, New York.

Rothwell, R. (1994): Towards the fifth-generation innovation process. International Marketing Review, 11 (1): 7-31.

Schumpeter, J. A. (1939): Business Cycles, A theoretical, Historical and Statistical Analysis of the Capitalist Process. McGraw-Hill Book Company, New York-Toronto-London.

Simmonds, K. (1986). Marketing as innovation: The eighth paradigm. Journal of Management Studies, 23 (5): 479-495.

Śledzik, K. (2013): Schumpeter's View on Innovation and Entrepreneurship. SSRN Electronic Journal, DOI: 10.2139/ssm.2257783

Szakály D. (2008): Innovációmenedzsment. Miskolci Egyetemi Kiadó, Miskolc.

Taferner, B. (2017): A next generation of innovation models? An integration of the innovation process model big picture towards the different generations models. Review of Innovation and Competitiveness, 3 (3): 47-60.

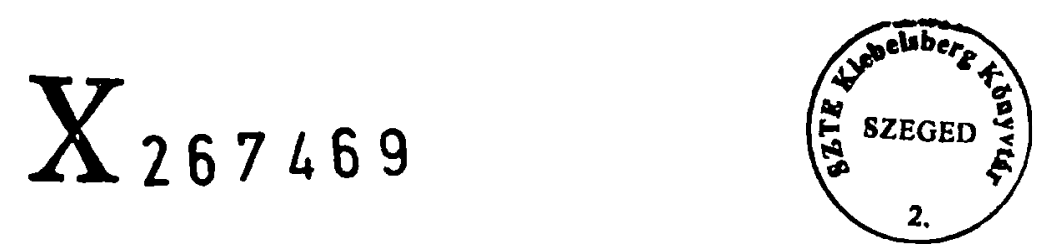

